\title{
Change and Biomedicine.
}

4 John C. Wingfield ${ }^{1}$, Nicole Perfito ${ }^{2}$, Rebecca Calisi $^{3}$, George Bentley $^{2}$, T. Ubuka ${ }^{4}$, M. Mukai $^{5}$,

$5 \quad$ Sara O’Brien $^{6}$, and K. Tsutsui ${ }^{4}$.

6

$7 \quad{ }^{1}$ Department of Neurobiology, Physiology and Behavior, University of California, One Shields

8 Avenue, Davis, CA 95616, USA.

$9{ }^{2}$ Department of Integrative Biology, University of California, Berkeley, CA 94720, USA.

$10{ }^{3}$ Department of Biology, Barnard College, Columbia University, New York, NY 10027, USA.

114 Department of Biology, Waseda University, Shinjuku-ku, Tokyo 162-8480, Japan.

$12{ }^{5}$ Department of Food Science, College of Agriculture and Life Sciences, Cornell University,

13 Ithaca, NY 14853, USA.

$14{ }^{5}$ Department of Biology, Radford University, Radford, VA 24142, USA.

15

16 Corresponding author: John C. Wingfield, jcwingfield@ucdavis.edu

17

18 Running Head: Putting the Brakes on Reproduction

19

20 


\section{Abstract.}

22 Seasonal breeding is widespread in vertebrates and involves sequential development of the

23 gonads, onset of breeding activities (e.g. cycling in females) and then termination resulting in

24 regression of the reproductive system. Whereas males generally show complete spermatogenesis

25 prior to and after onset of breeding, females of many vertebrate species show only partial ovarian

26 development and may delay onset of cycling (e.g. estrous), yolk deposition or germinal vesicle

27 breakdown until conditions conducive for ovulation and onset of breeding are favorable.

28 Regulation of this "brake" on the onset of breeding remains relatively unknown, but could have

29 profound implications for conservation efforts and for "mismatches" of breeding in relation to

30 global climate change. Using avian models it is proposed that a brain peptide, gonadotropin-

31 inhibitory hormone $(\mathrm{GnIH})$, may be the brake to prevent onset of breeding in females. Evidence

32 to date suggests that although GnIH may be involved in the regulation of gonadal development

33 and regression, it plays more regulatory roles in the process of final ovarian development leading

34 to ovulation, transitions from sexual to parental behavior and suppression of reproductive

35 function by environmental stress. Accumulating experimental evidence strongly suggests that

$36 \mathrm{GnIH}$ inhibits actions of gonadotropin-releasing hormones on behavior (central effects) and

37 gonadotropin secretion (central and hypophysiotropic effects), and has direct actions in the

38 gonad to inhibit steroidogenesis. Thus, actual onset of breeding activities leading to ovulation

39 may involve environmental cues releasing an inhibition (brake) on the hypothalamo-pituitary-

40 gonad axis.

41 Key Words: Reproduction, birds, gonadotropins, gonadotropin-releasing hormone,

42 gonadotropin-inhibitory hormone, environmental signals. 


\section{Introduction.}

45 Understanding the regulation of reproductive function is fundamental not only for biomedicine

46 but also for agriculture, aquaculture, conservation and sustainability of natural bio-resources for

47 harvest. In an age of burgeoning global change, elucidating the mechanisms underlying how

48 organisms respond to environmental cues and regulate reproductive function become more and

49 more important. To do this, it is essential that the reproductive process be analyzed at functional

50 levels so that critical experiments can be designed. In this way we can gain insight into how

51 environmental signals are perceived and then transduced through neural and neuroendocrine

52 pathways into morphological, physiological and behavioral responses that maximize

53 reproductive success (Visser, 2008; Wingfield, 2008a,b, 2012). Of particular importance is the

54 integration of neuroendocrine and endocrine mechanisms with ecology and evolutionary biology

55 to place neural pathways for environmental signals in context (e.g. MacDougall-Shackleton et al.,

56 2009; Visser et al., 2010). As climate changes and phenology of migrations, breeding seasons,

57 food supply, temperature, precipitation etc. shift, often in different ways, there is an increasing

58 awareness that phenological mismatches are occurring more and frequently. For example, the

59 great tit, Parus major, depends upon oak (Quercus sp) caterpillars in spring to feed young. The

60 timing of caterpillar emergence in northern Europe is changing and some populations, but not all,

61 of the great tit still breed at the same time resulting in a mismatch of environmental phenology

62 and timing of breeding (e.g. Visser et al., 2012). Why does this mismatch occur in some

63 populations and not others? The great tits showing a mismatch appear to be unable to respond to

64 changed environmental signals and no longer time egg-laying, and thus the hatching of chicks, to

65 coincide with the most favorable food supply. 
Other investigations have shown variation in responsiveness to local predictive cues in

67 terms of gonadal development. Lowland populations of song sparrows, Melospiza melodia

68 morphna, are less sensitive to temperature cues affecting photoperiodically-induced gonadal

69 growth than are high altitude populations (Perfito et al., 2005). In other species visual and tactile

70 cues relating to food availability can enhance gonadal development (e.g. Hau et al., 2000;

71 O'Brien and Hau, 2005; Furlonger et al., 2012) indicating that responsiveness, or not, to local

72 environmental cues varies across populations and in some could lead to mismatches of food

73 supply and reproductive function. What components of the "perception-transduction-response"

74 system (Wingfield and Mukai, 2009) fail to adjust to changed phenology?

75 To answer these important and urgent questions will require careful analysis of

76 phenology and the neural pathways for environmental signals in context (Visser et al., 2010).

77 This review focuses primarily on songbird species, such as the white-crowned sparrow,

78 Zonotrichia leucophrys, song sparrow, Melospiza melodia, and European starling, Sturnus

79 vulgaris. They have been studied in considerable detail both from the perspective of their

80 ecology and behavior under natural conditions and the neuroendocrinology and endocrinology of

81 reproductive function. Such approaches have the potential to allow us to predict which

82 populations will be able to cope with environmental change and which will not. Conservation

83 efforts could thus be focused on the latter.

84 Environmental and Endocrine Regulation of the Reproductive System.

85 At mechanistic levels it is crucial to bear in mind that reproduction involves ontogenetic

86 processes resulting in initial differentiation of the gonads and establishing sex (Crews and Moore,

87 1986; Wingfield, 2008a,b) followed by development of the reproductive system at puberty, and

88 subsequently in seasonally breeding species, on a yearly basis. The ontogenetic development 
89 leading to initial establishment of male or female sex in Aves is not repeatable whereas annual

90 development of the reproductive system in seasonal species is repeatable. This suggests

91 fundamentally different regulatory mechanisms for these different events. However, developing

92 a functional gonad is not the end point of the reproductive process, especially in females of

93 tetrapods. For example, in avian species development of the gonad results in "mature capability"

94 meaning that the individual is then capable of initiating a breeding attempt resulting in ovulation,

95 copulation and in many species, raising of young. Moreover, in species that breed seasonally or

96 periodically, reproductive function is terminated at the end of the breeding season and the gonads

97 show morphological and physiological regression to varying degrees. Reproductive behaviors

98 also frequently decline (Wingfield, 2008a).

99 A schematic diagram of the organization of the reproductive process in seasonally

100 breeding birds and for many mammals is given in Fig. 1 (see Wingfield, 2006). Note the three

101 phases of reproduction: development, mature capability (actual cycling of breeding attempts) and

102 termination. Each phase may be regulated differently. The mature capability phase is perhaps the

103 most complex because this involves onset of ovarian cycling in females leading to ovulation and

104 mating (Fig. 1). In many avian and mammalian species there follows a period of parental care

105 which can then lead to second breeding attempts, or if the nest and young are lost to predators, a

106 replacement breeding attempt can be initiated (Fig. 1). Note that mature capability is entirely

107 dependent upon the reproductive system being in a mature state so these nesting attempts -

108 sexual and parental sub-phases - can be initiated (Fig. 1). There are some exceptions to this rule

109 in mammals and other vertebrates (Crews and Moore, 1986), but this tends to be more uniformly

110 so in birds. 
111 We can now predict that multiple cues from the physical and social environments will

112 regulate complex transitions between sexual and parental sub-phases of mature capability (Fig.

113 1). When reproductive development is complete and the individual has mature capability, onset

114 of breeding does not necessarily occur immediately. In many species females are able to place a

115 "brake" on final maturation leading to ovulation and subsequently the parental phase, until

116 favorable cues from the physical and social environments release that brake. If those favorable

117 cues do not occur then females can maintain the brake on onset of breeding indefinitely, or until

118 the termination phase of reproductive function sets in. Therefore, it is possible that because of

119 climate change, favorable conditions may not occur in some years, or the individual is no longer

120 matched with those favorable conditions and females may even forego breeding for that year (e.g.

121 Visser et al., 2010, 2012).

122 What environmental cues are used to regulate, and time, reproductive function? The

123 literature is replete with hundreds, if not thousands, of reports indicating factors from physical

124 and social environments that can influence the reproductive process. Firstly, initial predictive

125 cues such as the seasonal change in day length are very reliable environmental cues that trigger

126 reproductive development, sustain mature capability through the breeding season and then

127 terminate reproductive function usually through gonadal regression (Fig. 2, see Dawson et al.,

128 2001; Bentley et al., 2007; Yoshimura, 2004; Wingfield and Silverin, 2002, 2009). Then there

129 are local predictive cues (supplementary factors) that speed up or slow down effects of initial

130 predictive cues so that mature capability and onset of breeding can be timed accurately. Local

131 predictive cues may also act on the termination phase (Fig. 2, Wingfield, 2006). Social cues

132 serve to synchronize individual reproductive function, such as between mates, and integrate

133 changes in sexual and parental sub-phases such as transition from sexual to parental behavior and 
134 the reverse for subsequent breeding attempts (Fig. 2). Note that all of these types of

135 environmental cues may have different mechanisms of action (perception, transduction, response,

136 Wingfield 2008b; 2012; Wingfield and Mukai, 2009) in each phase of the reproductive life

137 history stage (Fig. 2). It should also be noted that a fourth type of environmental cue, labile

138 perturbation factors also known as modifying factors, include the effects of unpredictable events

139 such as loss of the young or mates to predators and severe weather that disrupts reproductive

140 function (Wingfield et al., 1999; Wingfield and Silverin, 2002, 2009). Individuals responding to

141 perturbation factors interrupt the sexual and parental sub-phases and re-instate the "brake" on

142 breeding until the perturbation passes. If environmental conditions become conducive to onset of

143 breeding once more then the brake is released and a re-nest attempt is initiated (Wingfield and

144 Farner, 1979; Wingfield and Silverin, 2002, 2009).

145 Overall, field and laboratory investigations suggest that individuals do indeed hold in the

146 mature capability phase of the reproductive system until environmental conditions are favorable

147 for onset of final maturation of the ovary, ovulation and transition to the parental phase, but what

148 is the evidence for a "brake" on onset of breeding?

149 Evidence for a "Brake" on Onset of Breeding (Reproductive Cycling).

150 Finite-state machine theory points out that all adult life history stages have development, mature

151 capability and termination phases (Jacobs and Wingfield, 2000; Wingfield, 2008a). This

152 indicates that the timing of reproductive development and then onset of actual cycling (breeding)

153 are intimately related but regulated differently. For example, ovarian development in free-living

154 female white-crowned sparrows, Z. l. gambelii, progresses as day length increases in spring (Fig.

155 3). This reproductive baseline where the ovary reaches mature capability with selected follicles

156 up to $2 \mathrm{~mm}$ in diameter, may be held indefinitely until conditions conducive to breeding then 
157 result in final maturation of the ovary (yolking) leading to ovulation and onset of nesting (Fig. 3

158 and 4). Note that light shading indicates where final maturation of the ovary accompanied by

159 surges of plasma luteinizing hormone (LH) and estradiol levels occurs (Fig. 3). After egg-laying,

160 the ovary and plasma LH and estradiol, return to the breeding baseline (Fig. 3) suggesting that a

161 brake has been reset. Further surges of ovarian final maturation can occur in subsequent broods

162 or after loss of clutch or brood to a perturbation factors (Wingfield and Farner, 1978, 1979, 1993,

163 see Fig. 4). In contrast, testicular development in males progresses to mature capability and

164 remains much more uniform than in females (Fig. 3). In these males the brake is not so much on

165 testicular development but on surges of plasma $\mathrm{LH}$ and testosterone that occur in response to

166 sexual receptivity of females and interactions with other males (e.g. Wingfield et al., 1990, 1999).

167 This brake on final ovarian development can apparently be modified by experience.

168 Female song sparrows, M.m. melodia, captured from the wild and then photostimulated to induce

169 ovarian development, do not enter the final maturation of ovarian follicles or ovulate in captivity.

170 The ovary remains in mature capability until they turn photorefractory and the reproductive

171 system involutes. However, if they are taken through a second bout of photostimulation many of

172 these females then ovulate suggesting that there is some form of adjustment to captive conditions

173 allowing release of the brake on onset of breeding in subsequent reproductive cycles (J.C.

174 Wingfield, unpublished). Furthermore, female song sparrows captured as juveniles and raised in

175 captive conditions will also complete final maturation of the ovary when photostimulated (Fig. 5)

176 suggesting that some form of environmental "conditioning" is occurring so that local cues can

177 regulate final onset of breeding. Similar results in white-crowned sparrows show that hand raised

178 females lay eggs in captivity compared with wild caught females (Baptista and Petrinovich, 
179 1986). Males do not show these differences in testicular development with experience of

180 captivity but plasma levels of LH and testosterone may be affected (Wingfield et al., 1990, 1990).

181 It is entirely possible that visual information is an important cue, or set of cues, that

182 females use to regulate final ovarian development, but what is the evidence for a brake?

183 Bilaterally enucleated female white-crowned sparrows show enhanced ovarian development

184 when photostimulated (Yokoyama and Farner, 1976). Indeed many females showed large yolky

185 follicles and plasma levels of LH were elevated over uni-laterally enucleated and intact females

186 (Yokoyama and Farner, 1976, Fig.6). It was suggested that visual information may impart a tonic

187 inhibition (i.e. a brake) on final maturation of the ovary, and visual cues conducive to onset of

188 nesting then release that inhibition (brake). Disruption of this visual input results in release of the

189 inhibition and a spontaneous increase in gonadotropins and eventually full development of

190 ovarian follicles to near ovulation (Yokoyama and Farner, 1976). These authors were also

191 careful to point out that because the photoreceptors for photoperiodic effects on reproductive

192 state are in the hypothalamus, not the retina, it is possible that exposure of that part of the brain

193 by enucleation may have resulted in hyper-photostimulation and may not be indicative of

194 inhibition by visual information.

195 To resolve the potential issue of hyper-photostimulation we glued small plastic eye caps

196 to the rim of the eye socket of song and white-crowned sparrows by using Skinbond. First birds

197 were anesthetized with isofluorane and the small feathers of the eye ring removed. Plastic eye

198 caps tailored to fit over the eye ring were then glued in place. In some experiments birds with no

199 caps or with just a rim of plastic were used as controls (i.e. no impairment of vision, $n=6$ ). In

200 another experiment we used complete caps with clear plastic that also allowed full visual input (n

$201=6$, Fig. 7). Experimental groups were given plastic eye caps painted black and after gluing to 
202 the eye rim were coated with black neoprene glue to reduce scratching and effectively block all

203 light entering the eye ( $\mathrm{n}=7$, Fig. 7). Test of their ability to detect shadows revealed that they

204 were effectively blind. Nonetheless, several water bowls and dishes of food were provided so

205 they could easily eat and drink. A third group of birds received opaque plastic eye caps that had

206 been fogged so that light could enter the eye but the bird could not resolve images $(n=7$, Fig. 7).

207 Again these birds had copious food and water to enable them to eat and drink.

208 The eye caps were placed after about 20-30 days of photostimulation when ovarian

209 development was nearing mature capability. By the end of the experiment, volumes of the largest

210 developing follicle showed similar ranges from 0.06 to 14.10 cubic $\mathrm{mm}$ in both western song

211 sparrows, M.m. morphna and white-crowned sparrows, and from 0.06 to 65.40 cubic $\mathrm{mm}$ in

212 eastern song sparrows. In both subspecies of song sparrow, follicles tended to be larger in

213 females wearing black caps relative to clear-capped controls (Fig. 8). However, this difference

214 was significant only in western song sparrows, $(\mathrm{H}(2)=6.17, P=0.046 ;$ M. m. melodia $\mathrm{H}(2)=$

$2154.81, P=0.09$; Fig. 8). Western song sparrow females wearing black caps had significantly

216 larger follicles than birds wearing control caps ( $P<0.05$, Dunn's Method; Fig. 8). Follicle

217 volume in white-crowned sparrows did not differ among treatment groups $(\mathrm{H}(2)=2.99, P=$

218 0.22; Fig. 8). The final maturation of follicles before ovulation includes the deposition of yolk

219 that is visible during laparotomy. None of the females wearing clear caps began to deposit yolk

220 in follicles in any of the three groups, but yolk deposition did begin in females wearing fogged

221 and black caps. Two white-crowned sparrows (one each with fogged and black caps), four

222 eastern song sparrows (two each with fogged and black caps), and four western song sparrows

223 (one fogged and 3 black cap) females had visible yolk in the largest developing follicle (Fisher's

224 exact test, $P=0.011$, N. Perfito and J.C. Wingfield, unpublished). 
226 enucleation on final ovarian maturation in Z.l. gambelii whereas our capping experiments on the

227 same sub-species showed only a trend for ovarian follicle development and no effect on plasma

228 LH (Fig. 8). This may be because enucleation does indeed result in hyper-photostimulation,

229 although inhibitory actions of visual information could still be acting. In song sparrows also

230 there were no consistent differences in LH concentration through capping of the eyes (Fig. 8). In

231 M.m. melodia there was a trend for higher LH concentration in black-capped birds than in

232 controls, but these differences were not significant (Fig. 8). Since LH acts primarily to induce

233 sex steroid production in the gonad, increased follicular development could occur without

234 changes in LH levels. It is possible that FSH secretion was increased with this manipulation, and

235 is probably a more likely candidate to regulate differences in follicular growth. But the results

236 overall are encouraging, especially in song sparrows, that further exploration of this phenomenon

237 is warranted.

238 The variation among the responses of species in these capping experiments can be

239 explained in part using the paradigm suggested by Wingfield and colleagues $(1992,1993)$. Both

240 sub-species of song sparrow breed at mid-latitudes where spring breeding conditions vary from

241 year to year and onset of laying can vary by weeks or months (Nice 1937; Wingfield et al. 1992).

242 Under these conditions, individuals should be sensitive to a variety of environmental cues in

243 addition to photoperiod to time breeding. Our data on song sparrows are consistent with these

244 paradigms, and further suggest that local predictive cues may be perceived in part by the visual

245 system. In contrast, Z. l. gambelii breeds at high latitudes in the Arctic where the breeding season

246 is much more rigidly timed. Visual local predictive cues may be less important for final

247 maturation of the ovary and females rely primarily on photoperiodic cues. 
Because hyper-photostimulation is not an issue in the eye-capping experiment (eyes are

249 intact) these data are consistent with visual information imparting constant inhibitory signals to

250 the hypothalamo-pituitary-gonad axis (HPG-axis) which can be released by disruption of this

251 system (eye capping) or when the correct visual cues are perceived. Under natural conditions in

252 the field, female songbirds have the ability to interrupt follicular development until favorable

253 breeding conditions arrive and then quickly begin yolk deposition and egg-laying. (King et al.

254 1966; Kern and King 1972; Silverin et al. 1989). Individuals that are able to use visual

255 information (e.g. plant flowering, insect abundance, or snow melt) in advance of changes in food

256 intake would perhaps be at an advantage. Hau and colleagues (2000) have shown that purely

257 visual components of live insect food stimulate singing behavior in male spotted antbirds,

258 Hylophylax n. naevioides, before gonadal volume increases. Further, red crossbill, Loxia

259 curvirostra, males dramatically increased gonadal volume with perceived increase in food

260 abundance above males continuously fed ad libitum (Hahn 1995). Similar results were obtained

261 feeding standard pellet diet or supplemented with preferred seeds to American goldfinches,

262 Spinus tristis, resulting in greater development of ovarian follicles (Furlonger et al., 2012) These

263 findings indicate that visual input is stimulatory to gonadal development, presumably by

264 removing inhibitory cues present in the laboratory setting. Are there any candidates for neural or

265 neuroendocrine factors that might provide such inhibition?

\section{A Candidate for the Brake: Inhibition of Onset of Breeding.}

267 In vertebrates there are several forms of $\mathrm{GnRH}$ in the hypothalamus that regulate gonadotropin

268 release from the anterior pituitary (hypophysiotropic effects) or act centrally on reproductive

269 behavior. Two other peptides, kisspeptin and gonadotropin-inhibitory hormone (GnIH), act

270 respectively to increase or decrease efficacy of GnRH (Tsutsui et al., 2000; Tsutsui et al., 2010b; 
271 Parhar et al., 2012). However, in birds the kisspeptin gene is yet to be identified (Tsutsui et al.,

272 2010b) and here we will focus on $\mathrm{GnIH}$ as a primary candidate for the brake on reproductive

273 onset (Tsutsui et al., 2006, 2007, 2012). GnIH and related peptides have now been isolated from

274 the brains of all major vertebrate groups, (Tsutsui 2009; Tsutsui et al., 2010a,b, 2013) including

275 songbirds (Bentley et al., 2003).

276 GnIH can inhibit LH release in songbirds both hypophysiotropically and centrally

277 through inhibition of GnRH release (Fig. 9., Osugi et al., 2004; Bentley et al., 2006a,b, 2008;

278 Ubuka et al., 2008b; O'Brien, 2009). It is very clear that GnIH does not affect breeding baseline

279 LH but blocks surges of LH above the breeding baseline possibly associated with $\mathrm{GnRH}$

280 stimulation (Bentley et al., 2003; Osugi et al., 2004), and with onset of breeding in free-living

281 male Z.l. gambelii compared with later in the breeding season when LH levels decline to the

282 breeding baseline (O’Brien, 2009). Infusion of GnIH via mini-osmotic pumps results in a

283 sustained decline in plasma levels of LH and increased mRNA for GnIH in the PVN, but had no

284 effects on testis size or spermatogenesis in white-crowned sparrows (O'Brien, 2009).

285 Although GnIH in the brain is only expressed in neurons in the paraventricular nucleus

286 (Osugi et al., 2004; O’Brien, 2009), its receptors (GnIH-R; Yin et al., 2005) are expressed widely

287 including on GnRH-I and GnRH-II neurons in avian brain (Ubuka et al., 2008a). The GnIH gene

288 and the GnIH-R are also expressed in the ovary and testis suggesting multiple actions on

289 reproductive function at several levels in the HPG axis (Bentley et al., 2008, 2009, 2010;

290 Maddineni, et al., 2008). Actions in mammals and other vertebrates are similar (Bentley et al.,

2912006 a,b; 2010; Calisi, 2014) and whereas mechanisms may vary across species evidence is

292 building that $\mathrm{GnIH}$ plays a key role in regulation seasonal reproduction and sexual motivation

293 (O'Brien, 2009; Kriegsfeld et al., 2010, 2015). In birds injection of GnIH into the third ventricle 
294 can rapidly decrease female sexual behavior (copulation solicitation displays) stimulated by

295 estradiol implants and GnRH-II (Bentley et al., 2006a). Similar results of GnIH infusion on male

296 sexual behavior have been found in rodents also (Johnson et al., 2007). GnIH may mediate these

297 effects centrally by expressing GnIH-receptors on GnRH-I and GnRH-II neurons through G-

298 protein coupled signaling (Ubuka et al., 2013b). In mice, direct application of mammalian RF-

299 amide related peptide to GnRH cells in cultured brain slices decreases firing rate in a

300 subpopulation of cells, further suggesting a direct action of GnIH on GnRH neurons (Ducret et

301 al. 2009; Wu et al. 2009)

302 Possible Role of GnIH in Responses to Perturbations of the Environment.

303 Acute environmental perturbations have long been known to inhibit reproductive function,

304 particularly onset of breeding or even interruption of breeding (e.g. Wingfield et al., 1999). More

305 recently, Deviche et al. (2012) showed that capture and handling stress in the rufous-winged

306 sparrow, Peucaea carpalis, resulted in a decline of plasma testosterone in 10-30 minutes while

307 plasma levels of LH were unaffected. Injection of GnRH increased plasma levels of LH in both

308 stressed and unstressed birds. Similarly ovine LH injections resulted in elevated testosterone

309 regardless of whether they were stressed (Deviche et al., 2010). These authors concluded that the

310 acute stress-induced decline in testosterone is not mediated through reduced sensitivity of the

311 anterior pituitary gland to GnRH or sensitivity of the testis to LH. Circulating levels of

312 corticosterone were elevated during this procedure but it remains unknown whether

313 corticosterone directly inhibited testosterone release at the level of the testis (Deviche et al.,

314 2012). Stress may inhibit reproduction through release of GnIH followed by rapid inhibition of

315 LH release, gonad steroid production and decreased sexual behavior (Calisi et al., 2008; Calisi,

316 2014). In house sparrows, Passer domesticus, acute stress resulted in an increase in hypothalamic 
317 cells showing immunoreactive GnIH. Furthermore, this effect was only seen in breeding males

318 and females but not in the non-breeding season suggesting effects of $\mathrm{GnIH}$ are restricted to

319 regulation of reproductive function (Calisi et al., 2008). More recent evidence in mammals and

320 birds indicates that glucocorticoid receptors (GRs) are expressed in neurons containing $\mathrm{GnIH}$

321 (Calisi, 2014; Kirby et al., 2009; Son et al., 2014). In rats, adrenalectomy resulted in attenuation

322 of the GnIH response to acute stress (Kirby et al., 2009). Similarly, Geraghty et al. (2015)

323 showed that genetic silencing of RFamide-related peptide $3(\mathrm{GnIH})$ reversed chronic stress-

324 induced infertility in female rats. Dexamethasone treatment of immortalized hypothalamic

325 neurons increased GnIH and its receptor expressions through a GR mediated mechanism.

326 Estradiol treatment had no effect suggesting that GnIH function may play an important

327 regulatory role in mediating stress-induced suppression of reproduction (Gojska and Belsham,

328 2014). Moreover, in Japanese quail, GR mRNA has been localized in GnIH expressing neurons

329 in the PVN (Son et al., 2014). Treatment with exogenous corticosterone increased GnIH

330 expression within the quail diencephalon suggesting that $\mathrm{GnIH}$ may mediate some aspects of the

331 inhibitory effects of environmental stress on reproductive function (Son et al., 2014).

332 In the European starling captive pairs kept in semi-free-ranging conditions in outdoor

333 flight aviaries with nest boxes breed freely compared with pairs held indoor flight cages with a

334 nest box (Dickens and Bentley, 2014). This experimental design is ideal to explore possible

335 mechanisms by which onset of breeding (nest building, egg-laying etc.) may be controlled.

336 Although all males had fully developed testes, regardless of treatment, only females in the

337 outdoor aviaries underwent final maturation of ovarian follicles leading to egg laying. Plasma

338 levels of testosterone were generally lower in male starlings housed indoors versus the birds

339 breeding in outdoor aviaries. In both males and females, baseline plasma corticosterone and 
340 acute stress-induced levels tended to be lower in the indoor birds compared with those housed

341 outdoors (Dickens and Bentley, 2014). Immunohistochemistry of GnRH cells in the

342 hypothalamus showed an interaction of treatment with higher levels in outdoor males compared

343 to females and indoor males. However, there were no differences in numbers of GnIH positive

344 cells. Furthermore, there were no effects of treatment on GnRH or GnIH gene expression in the

345 hypothalamus. Gene expression of CRH in relation to the stress response and GR as a possible

346 mechanism to inhibit breeding showed no effects in relation to treatment at the hypothalamic

347 level. Moreover, there was an effect of sex on GR, but no effect of treatment was observed

348 (Dickens and Bentley, 2014). In the pituitary gland gene expression for FSH $\beta$ subunit and GR

349 were the same in outdoor and indoor birds.

350 Dickens and Bentley (2014) went on to show that there was a significant increase in

$351 \mathrm{GnIH}$ gene expression in the ovaries of indoor females but no differences in testes in outdoor and

352 indoor birds. These authors found no significant differences in gonadotropin receptor expression,

353 aromatase, $17 \beta$ - hydroxysteroid dehydrogenase $/ \Delta^{5}-\Delta^{4}$-isomerase (17ß-HSD) or GR with

354 treatment in either males or females. This very detailed and extensive study suggests that

355 suppression of onset of breeding in female starlings may be associated with enhanced $\mathrm{GnIH}$

356 actions in the ovary rather than at the central level.

357 Injection of lipopolysaccharide (LPS) is often used to mimic the effects of a bacterial

358 infection that in turn activates the immune system with downstream effects on the HPA axis.

359 Well known behavioral effects such as reduced appetite and sickness behavior follow and in wild

360 species may be accompanied by an interruption of breeding (Lopes et al., 2012). LPS treatment

361 of male zebra finches, Taenopygia guttata, revealed a trend for decreased plasma testosterone

362 levels and elevated corticosterone concentrations but these were not quite significant. LPS 
363 injection also decreased hypothalamic GnRH-I gene expression and immunoreactive GnRH but

364 had no effect on GnIH gene expression or immunoreactivity (Lopes et al., 2012).

365 Intracerebral infusion of GnIH and its related peptides (GnIH-RP-1 and GnIH-RP-2)

366 stimulated an increase in food intake in domestic fowl chicks, Gallus gallus, (Tachibana et al.,

367 2005). Interestingly, these authors showed that infusion of anti-GnIH serum did not suppress

368 feeding when food was provided ad libitum but did inhibit appetite induced by fasting. High

369 ambient temperature can inhibit food intake in domestic fowl, and exposure to high ambient

370 temperature for 24-48 hours resulted in elevated expression of GnIH precursor mRNA

371 (Chowdhury et al., 2012). These authors suggest that high temperature-induced reduction in food

372 intake may be opposed by the resulting increase in GnIH expression in the PVN. On the other

373 hand, a $10 \mathrm{~h}$ period of fasting in male zebra finches increased circulating levels of corticosterone

374 and decreased plasma testosterone, but hypothalamic gene expression for GnRH-I and GnIH

375 were not affected (Lynn et al., 2015). However, birds with elevated corticosterone showed

376 greater gene expression for GnIH in the testis whereas expression of the StAR and LH receptor

377 (LH-R) genes were decreased indicating reduced sensitivity to circulating LH and lower

378 testosterone synthesis. Clearly fasting effects on reproductive function were mediated through

379 testicular adjustments of GnIH release rather directly through traditional GnRH hypothalamic

380 control. Lynn et al. (2015) suggest that local testicular control of sex steroid release may provide

381 a rapid and flexible response to environmental perturbations such as changes in food supply.

$382 \quad$ Presence of GR in the gonads suggests direct responsiveness to stress via this pathway

383 thus short circuiting the hypothalamo-pituitary axis of environmental signal transduction (e.g.

384 McGuire et al., 2013; Lynn et al., 2014). Food cues could also be directly measured through

385 metabolite levels in blood. Using European starling gonads in culture, McGuire et al. (2013) 
386 showed that corticosterone and metabolic challenges delivered through 2-deoxy-D-glucose

387 (2DG) and ethyl-2-mercaptoacetate (MA) decreased testosterone and estradiol production even

388 in the presence of LH and FSH. This effect was most pronounced early in the breeding season

389 and may be mediated through up-regulation of $\mathrm{GnIH}$ in the gonads. Testes of starlings respond to

390 corticosterone by increasing $\mathrm{GnIH}$ expression whereas ovaries respond to metabolic cues by also

391 increasing GnIH expression. GnIH then directly inhibits sex steroid production potentially

392 bypassing regulatory neuroendocrine and endocrine secretions of the HPG axis (McGuire et al.,

393 2013). Furthermore, human gonadotropin-inhibitory hormone ortholog RFamide-related peptide-

3943 inhibited progesterone production in human granulosa cells incubated with gonadotropin

395 (Oishi et al., 2012). Environmental cues that have direct effects on endocrine tissues rather than

396 be signalized through the brain and hypothalamus may be more frequent than we realize

397 (Wingfield, 2015).

398 There is growing evidence that glucocorticoid levels during development as well as in

399 response to local environmental conditions, food availability etc. can have profound effects on

400 the timing of breeding (Schoech et al., 2009). In other words, glucocorticoid secretion may

401 determine current investment of an individual in reproduction (low levels of glucocorticoids)

402 versus self-preservation (higher levels of glucocorticoids, see Angelier et al., 2007; Angelier and

403 Wingfield, 2013).

404 GnIH and Transitions Between Sexual and Parental Phases of Reproduction.

405 European starlings held in semi-natural conditions in a large flight aviary will initiate final

406 maturation of the ovary and lay eggs if pairs have access to nest boxes. At the start of the

407 breeding season, males and females with a nest box had significantly fewer GnIH expressing

408 neurons, smaller GnIH soma sizes and were estimated to be producing less GnIH peptide than 
409 birds without a nest box (Amorin and Calisi, 2015; Calisi et al., 2011). Later in the season, at the

410 beginning of the parental phase of nesting the numbers of $\mathrm{GnIH}$ expressing neurons were now in

411 greater abundance, GnIH cell soma sizes were larger and the estimated amount of GnIH peptide

412 production had increased in both sexes compared to those without a box, suggesting that $\mathrm{GnIH}$

413 may put a brake on further nesting once there are eggs and young in the nest (Calisi et al, 2011;

414 Amorin and Calisi, 2015). These authors also showed that GnRH content, testosterone and

415 corticosterone were not good indicators of nest box ownership. In European starlings, females

416 housed in semi-natural enclosures isolated from males did not show any final maturation of

417 ovarian follicles. However, females housed with males, or exposed to males for 7 days, showed

418 marked yolk deposition and final ovarian follicle maturation but with no changes in $\mathrm{GnIH}$

419 (Perfito et al., 2014).

420 The zebra finch is also an excellent model for investigations of environmental control of

421 life cycles because it is able to breed essentially year round - i.e. it is a nomadic and

422 opportunistic breeder. It is thought that in this species there may be tonic expression of GnRH

423 gene with modulation by GnIH expression according to environmental conditions (Perfito et al.,

424 2011). Investigations of wild-caught male zebra finches from southern and central Australia

425 showed that there were no differences in GnRH or GnIH expressions in the hypothalamus with

426 season or age (juveniles). These data suggest that seasonal (periodic) changes in reproductive

427 function, including gonadotropin levels are not mirrored in changes in $\mathrm{GnRH}$ and $\mathrm{GnIH}$

428 expressions (Perfito et al., 2011). These results are consistent with the hypothesis that GnRH

429 expression should be tonic in an opportunistically-breeding bird. Perfito et al. (2011) did find

430 that expression of GnRH-II in the mid brain changed with season with breeding males having 
431 more and larger GnRH-II expressing neurons. Behavioral effects through GnRH-II may an

432 important additional control point for seasonal/periodic breeding.

433 Hypothalamic actions of GnIH may be more important for social interactions and gonadal

$434 \mathrm{GnIH}$ for breeding and social interactions (through regulation of sex steroids). In Japanese quail,

435 interactions of males with sexually mature females result in a transient decline in $\mathrm{LH}$ and

436 testosterone (Cornil et al., 2009). More recently it has been shown that the presence of females

437 increases norepinephrine release in the PVN of males resulting, counter-intuitively, in an

438 elevation of GnIH gene expression and ultimately a decrease in plasma LH (Tobari et al., 2014).

439 In male quail neuroestrogens resulting from direct activation of aromatase in the pre-optic area

440 (POA) appear to inhibit socio-sexual behavior (Ubuka et al., 2014). There is a daily rhythm in

441 expression of sexual behavior in male quail with a peak in the morning hours when

442 neuroestrogen synthesis in the POA is low followed by an increase later in the day and a decline

443 in male sexual behavior. GnIH infusion centrally into male quail in the morning inhibits socio-

444 sexual behavior. Infusion of estradiol-17 $\beta$ at this time has a similar effect (Ubuka et al., 2014).

\section{Inhibition of GnIH Expression.}

446 To further investigate the role of $\mathrm{GnIH}$ in reproductive function, it is essential to decrease $\mathrm{GnIH}$

447 secretion experimentally. RNA interference experiments in Japanese quail and Gambell's white-

448 crowned sparrows successfully decreased GnIH mRNA in the PVN as well as GnIH peptide

449 (Ubuka et al., 2012, 2013a). GnIH precursor mRNA (GnIH siRNA) infused directly into the

450 third ventricle of white-crowned sparrows resulted in dramatic arousal and expression of

451 complex behavior. This was best summarized as reduced resting time (Ubuka et al., 2012)

452 including spontaneous production of complex vocalizations. Furthermore, a decrease in GnIH

453 expression stimulated brief agonistic vocalizations resembling those of breeding birds, both 
454 males and females, during territorial defense and formation of pair bonds. Most striking was a

455 marked increase in copulation solicitations in treated females exposed to playback of recorded

456 male song (Ubuka et al., 2012) consistent with earlier studies showing that GnIH infusion

457 inhibits copulation solicitation in estradiol-treated female sparrows (Bentley et al., 2006a). In

458 Japanese quail, central administration of GnIH siRNA resulted in spontaneous increases in

459 aggressive and sexual behaviors (Ubuka et al., 2013a). Moreover, GnIH administration into

460 GnIH RNAi treated male quail reinstated aggressive and sexual behaviors (Ubuka et al., 2013a).

461 Flexibility and Plasticity of Control Systems: Implications for Global Climate Change.

462 In summary, GnIH may have multiple functions as a central nervous system suppressor of social

463 interactions, particularly the control of reproductive behavior and general aggression including,

464 possibly, territorial defense. GnIH may play additional integrating roles in the temporal

465 regulation of reproduction in mammals and birds by environmental factors, physical and social

466 (Parhar et al., 2012; Tsutsui et al., 2013), particularly the onset of actual breeding and transitions

467 between sexual and parental phases of cycling. An additional emerging concept is the action of

$468 \mathrm{GnIH}$ expression in the gonads and the presence of $\mathrm{GnIH}$ receptors on steroid synthesizing cells

469 that may likely regulate sex steroid production, particularly in females, associated with final

470 ovarian development. This suggests that some responses to environmental cues may bypass the

$471 \mathrm{CNS}$ and neural pathways. Taken together, the evidence to date indicates that GnIH acting

472 centrally, hypophysiotropically and at the level of the gonads may be the "brake on onset of

473 cycling" critical for maximizing reproductive success.

474 This purported role of GnIH has clear implications for biomedicine, such as human

475 fertility, contraception and other reproductive issues. Similarly for reproductive function in

476 agricultural livestock, a role of $\mathrm{GnIH}$ will be important. But, there is also a possible important 
477 role for $\mathrm{GnIH}$ in conservation biology of endangered and threatened vertebrates that fail to

478 reproduce in captive breeding programs, or free-living populations that are declining because of

479 mismatches of environmental phenology and reproductive development. Much more

480 investigation is needed to explore organism-environment interaction and how $\mathrm{GnIH}$ is an

481 integrator of physical and social environmental cues that in turn regulate many aspects of the life

482 cycle. For example, GnIH studies may pinpoint populations that are less able to cope with

483 climate change and identify or predict which species conservation efforts should be focused on.

484 For the first time we are able to explore how onset of reproductive cycling is actually triggered in 485 appropriate natural settings.

487 Acknowledgments.

488 The senior author is grateful for grants RO1 MH65974-01 from the NIH, grants IBN-9905679, 489 IBN-0317141 and IOS-0750540 from the National Science Foundation, and the Endowed Chair 490 in Physiology from the University of California, Davis.

\section{References.}

493 Amorin, Nelson, and Calisi, R.M. 2015. Measurements of neuronal soma size and estimated 494 peptide concentration in addition to cell abundance offer a higher resolution of seasonal 495 and reproductive influences of GnRH-I and GnIH in European starlings. Integ. Comp.

497 Angelier, F., Wingfield, J.C., 2013. Importance of the glucocorticoid stress response in a 498 changing world: theory, hypotheses and perspectives. Gen. Comp. Endocrinol. 190, 118499 128. 
500 Angelier, F., Weimerskirch, H., Dano, S., Chastel, O., 2007. Age, experience and reproductive performance in a long-lived bird: a hormonal perspective. Behav. Ecol. Sociobiol. 61, 611-621.

503 Baptista, L.F., and Petrinovich, L. 1986. Egg production in hand-raised white-crowned sparrows. 504 Condor 88, 379-380.

505 Bentley, G.E., Perfito, N., Ukena, K., Tsutsui, K., Wingfield, J.C. 2003. Gonadotropin-inhibitory 506 peptide in song sparrows (Melospiza melodia) in different reproductive conditions, and in 507 house sparrows (Passer domesticus) relative to chicken-gonadotropin-releasing hormone. $508 \quad$ J. Neuroendocrinol. 15, 794-802.

509 Bentley, G.E., Jensen, J.P., Kaur, G.J., Wacker, D.W., Tsutsui, K., Wingfield, J.C., 2006a. Rapid 510 inhibition of female sexual behavior by gonadotropin-inhibitory hormone (GnIH). Horm. $511 \quad$ Behav. 49, 550-555.

512 Bentley, G.E., Kriegsfeld, L.J., Osugi, T., Ukena, K., O’Brien, S., Perfito, N., Moore, I.T.,

513 Tsutsui, K., Wingfield, J.C., 2006b. Interactions of gonadotropin-releasing hormone

$514(\mathrm{GnRH})$ and gonadotropin-inhibitory hormone $(\mathrm{GnIH})$ in birds and mammals. J. Exp.

$515 \quad$ Zool. 305A, 807-814.

516 Bentley, G.E., Perfito, N., Ubuka, T., Ukena, K., Osugi, T., O,Brien, S., Tsutsui, K., Wingfield,

517 J.C., 2007. Gonadotropin-inhibitory hormone in seasonally-breeding songbirds:

518 neuroanatomy and functional biology. J. Ornithol. 148 (Supplement 2), S521-S526.

519 Bentley, G.E., Ubuka, T., McGuire, N.L., Chowdhury, V.S., Morita, Y., Yano, T., Hasunuma, I.,

520 Binns, M. Wingfield, J.C., Tsutsui, K., 2008. Gonadotropin-inhibitory hormone and its 521 receptor in the avian reproductive system. Gen. Comp. Endocrinol. 156, 34-43. 
522 Bentley, G.E., Tsutsui, K., Kriegsfeld, L.C., 2010. Recent studies of gonadotropin-inhibitory

523 hormone $(\mathrm{GnIH})$ in the mammalian hypothalamus, pituitary and gonads. Brain Res. 1364, $524 \quad 62-67$.

525 Bentley, G.E., Ubuka, T., McGuire, N.L., Calisi, R., Perfito, N., Kriegsfeld, L.J., Wingfield, J.C.,

526 Tsutsui, K., 2009. Gonadotropin-inhibitory hormone: a multifunctional neuropeptide. J.

$527 \quad$ Neuroendocrinol. 21, 276-281.

528 Calisi, R.M., 2014. An integrative overview of the role of gonadotropin-inhibiting hormone in 529 behavior: applying Tinbergen's four questions. Gen. Comp. Endocrinol.

$530 \quad$ doi.org/10.1016/j.ygcen.2014.03.028

531 Calisi, R.M., Rizzo, N.O., Bentley, G.E., 2008. Seasonal differences in hypothalamic EGR-1 and

532 GnIH expression following capture-handling stress in house sparrows (Passer

533 domesticus). Gen. Comp. Endocrinol. 157, 283-287.

534 Calisi, R.M., Diaz-Muñoz, S.L., Wingfield, J.C., Bentley, G.E., 2011. Social and breeding status

535 are associated with the expression of GnIH. Genes Brain Behav. 10, 557-564.

536 Chowdhury, V.S., Tomonaga, S., Nishimura, S., Tabata, S., Cockem, J.F., Tsutsui, K., Furuse,

537 M., 2012. Hypothalamic gonadotropin-inhibitory hormone precursor mRNA is increased

538 during depressed food intake in heat-exposed chicks. Comp. Biochem. Physiol. A 162,

$539 \quad 227-233$.

540 Cornil, C.A., Stevenson, T.J., Ball, G.F., 2009. Are rapid changes in gonadal testosterone

541 release involved in the fast modulation of brain estrogen effects? Gen. Comp. Endocrinol.

$542 \quad 163,298-305$.

543 Crews, D., Moore, M.C., 1986. Evolution of mechanisms controlling mating behavior. Science $544 \quad 231,121-125$. 
545 Dawson, A., King, V.M., Bentley, G.E., Ball, G.F., 2001. Photoperiodic control of seasonality in $546 \quad$ birds. J. Biol. Rhythms 16, 365-380.

547 Deviche, P., Gao, S., Davies, S., Sharp, P.J., Dawson, A., 2012. Rapid stress-induced inhibition 548 of plasma testosterone in free-ranging male rufous-winged sparrows, Peucaea carpalis: 549 characterization, time course, and recovery. Gen. Comp. Endocrinol. 177, 1-8.

550 Deviche, P., Hurley, L.L., Fokoidis, H.B., Lerbour, B., Silverin, B., Silverin, Bj., Sabo, J., Sharp, 551 P.J., 2010. Acute stress rapidly decreases plasma testosterone in a free-ranging male 552 songbird: potential site of action and mechanisms. Gen. Comp. Endocrinol. 169, 82-90.

553 Dickens, MM.J., Bentley, G.E., 2014. Stress, captivity, and reproduction in a wild bird species. $554 \quad$ Horm. Behav. 66, 685-693.

555 Ducret, E. Anderson, G.M., Herbison, A.E. 2009.RFamide-related peptide-3, a mammalian 556 gonadotropin-inhibitory hormone ortholog, regulates gonadotropin-releasing hormone 557 neuron firing in the mouse. Endocrinol. 150, 2799-2804.

558 Furlonger, A.A., Huyn, L., Luloff, T.W., Schmidt, K.L., and MacDougall-Shackleton, S.A. 559 (2012). Effects of supplementation with preferred foods on the reproductive axis of 560 American goldfinches (Spinus tristis). Can. J. Zool. 90, 203-209.

561 Geraghty, A.C., Muroy, S.E., Zhao, S., Bentley, G.E., Kriegsfeld, L.J., and Kaufer, D. 2015.

$562 \quad$ Knockdown of hypothalamic RFRP3 prevents chronic stress-induced infertility and 563 embryo resorption. eLIFE DOI: 10.7554/eLIFE.04316.

564 Gojska, N.M., Belsham, D.D., 2014. Glucocorticoid receptor-mediated regulation of Rfrp

$565(\mathrm{GnIH})$ and $\operatorname{Gpr} 147(\mathrm{GnIH}-\mathrm{R})$ synthesis in immortalized hypothalamic neurons. Mol.

$566 \quad$ Cell. Endocrinol. 384, 23-31.

567 Hahn, T. P., 1995. Integration of photoperiodic and food cues to time changes in reproductive 
physiology by an opportunistic breeder, the red crossbill, Loxia curvirostra (Aves:

569 Carduelinae). J. Exp. Zool. 272, 213-226.

570 Hau, M., M. Wikelski, J. C. Wingfield, 2000. Visual and nutritional food cues fine-tune timing

571 of reproduction in a neotropical rainforest bird. J. Exp. Zool. 286, 494-504.

572 Jacobs, J.D., Wingfield, J.C., 2000. Endocrine control of life-cycle stages: a constraint on

573 response to the environment? Condor 102, 35-51.

574 Johnson, M.A., Tsutsui, K., Fraley, G.S., 2007. Rat RFamide-related peptide-3 stimulates GH

575 secretion, Inhibits LH secretion, and has variable effects on sex behavior in the adult

576 male rat. Horm. Behav. 51, 171-180.

577 Kern, M. D., J. R. King, 1972. Testosterone-induced singing in female White-crowned

$578 \quad$ sparrows. Condor 74, 204-209.

579 King, J. R., B. K. Follett, D. S. Farner, M. L. Morton, 1966. Annual gonadal cycles and

580 pituitary gonadotropins in Zonotrichia leucophrys gambelii. Condor 68, 476-487.

581 Kirby, E.D., Geraghty, A.C., Ubuka, T., Bentley, G.E., Kaufer, D., 2009. Stress increases

582 putative gonadotropin inhibitory hormone and decreases luteinizing hormone in male rats.

583 Proc. Natl. Acad. Sci. USA 106, 11324-11329.

584 Kriegsfeld, L.J., Gibson, E.M., Williams, W.P. III, Mason, A.O., Bentley, G.E., Tsutsui, K.,

585 2010. The roles of RFamide-related peptide-3 in mammalian reproduction and behavior.

$586 \quad$ J. Neuroendocrinol. 22, 692-700.

587 Kriegsfeld, L.J., Ubuka, T., Bentley, G.E., Tsutsui, K., 2015. Seasonal control of gonadotropin-

588 inhibitory hormone $(\mathrm{GnIH})$ in birds and mammals. Front. Neuroendocrinol. Doi:

$589 \quad 10.1016 / j . y f r n e .2014 .12 .001$. in press 
590 Lopes, P.C., Wingfield, J.C., Bentley, G.E., 2012. Lipopolysaccharide injection induces rapid 591 decrease of hypothalamic GnRH mRNA and peptide, but does not affect GnIH in zebra 592 finches. Horm. Behav. doi:10.1016/j.yhbeh.2012.06.007

593 Lynn, S.E., Perfito, N., Guardado, D., Bentley, G.E., 2015. Food, stress, and circulating 594 testosterone: cue integration by the testes, not the brain, in male zebra finches 595 (Taenopygia guttata). Gen. Comp. Endocrinol. 21,5 1-9.

596 MacDougall-Shackleton, S.A., Stevenson, T.J., Watts, H.E., Pereyra, M.E., and Hahn, T.P. 2009.

597 The evolution of photoperiod response systems and seasonal GnRH plasticity in birds.

$598 \quad$ Integ. Comp. Biol. Doi: 10.1093/icb/icp048

599 Maddineni, S.R., Ocón-Grove, O.M., Krzysik-Walker, S.M., Hendricks III, G.L., Ramachandran,

600 R., 2008. Gonadotropin-inhibitory hormone $(\mathrm{GnIH})$ receptor gene is expressed in the

601 chicken ovary: potential role of GnIH in follicular maturation. Reproduction 135, 267$602 \quad 274$.

603 McGuire, N.L., Koh, A., Bentley, G.E., 2013. The direct response of the gonads to cues of stress 604 in a temperate songbird species is season-dependent. Peer J. DOI 10.7717/peerj.139

605 Nice, M. M., 1937. Studies in the Life History of the Song Sparrow. New York, Dover 606 Publications, Inc.

607 O'Brien, S., 2009. The characterization of gonadotropin-inhibitory hormone (GnIH) and it's role 608 in fine-tuning reproduction in the white-crowned sparrow (Zonotrichia leucophrys). Ph.D. 609 Thesis, University of Washington.

610 O'Brien, S., and Hau, M. 2005. Food cues and gonadal development in neotropical spotted 611 antbirds (Hylophylax naevioides). J. Ornithol. DOI 10.1007/s10336-005-0013-9 
612 Oishi, H., Klausen, C., Bentley, G.E., Osugi, T., Tsutsui, K., Gilks, C.B., Yano, T., and Leung,

613 P.C. 2012. The human gonadotropin-inhibitory hormone ortholog RFamide-related

614 peptide-3 suppresses gonadotropin-induced progesterone production in human granulosa

$615 \quad$ cells. Endocrinol. 153, 3435-3445.

616 Osugi, T., Ukena, K., Bentley, G.F., O’Brien, S., Moore, I.T., Wingfield, J.C., Tsutsui, K. (2004).

617 Gonadotropin-inhibitory hormone in Gambel's white-crowned sparrow (Zonotrichia

618 leucophrys gambelii): cDNA identification, transcript localization and functional effects

619 in laboratory and field experiments. J. Endocrinol.182, 33-42.

620 Parhar, I., Ogawa, S., and Kitahashi, T. 2012. RFamide peptides as mediators in environmental 621 control of GnRH neurons. Prog. Neurobiol. 98, 176-196.

622 Perfito, N., Guardado, D., Williams, T.D., and Bentley, G.E. 2014. Social cues regulate

623 switching of hypothalamic Dio2/Dio3 and the transition into final follicle maturation in

624 European starlings (Sturnus vulgaris). Endocrinol. DOI:

$625 \quad$ http://dx.doi.org/10.1210/en.2014-1450

626 Perfito, N., Meddle, S.L., Tramontin, A.D., Sharp, P.J., and Wingfield, J.C. 2005. Seasonal

627 gonadal recrudescence in song sparrows: response to temperature cues. Gen. Comp.

$628 \quad$ Endocrinol. 143, 121-128.

629 Perfito, N., Zann, R., Ubuka, T., Bentley, G.E., Hau, M., 2011. Potential roles for GnIH and 630 GnRH-II in reproductive axis regulation of an opportunistically breeding songbird. Gen. 631 Comp. Endocrinol. 173, 20-26.

632 Schoech, S.J., Rensel, M.A., Bridge, E.S., Boughton, R.K., Wilcoxen, T.E., 2009. Environment, 633 glucocorticoids, and the timing of reproduction. Gen. Comp. Endocrinol. 163, 201-207.

634 Silverin, B., P. A. Viebke, Westin, J., 1989. An artificial stimulation of the vernal increase in day 
length and its effects on the reproductive system in three species of tits (Parus spp.), and modifying effects of environmental factors - a field experiment. Condor 91, 598-608.

637 Son, Y.L., Ubuka, T., Narihiro, M., Fukuda, Y., Hasunuma, I., Yamamoto, K., Belsham, D.D.,

638 Tsutsui, K., 2014. Molecular basis for the activation of gonadotropin-inhibitory hormone 639 gene transcription by corticosterone. Endocrinol. 155, 1817-1826.

640 Tachibana, T., Sato, M., Takahashi, H., Ukena, K., Tsutsui, K., Furuse, M., 2005.

641 Gonadotropin-inhibiting hormone stimulates feeding behavior in chicks. Brain Res. 1050, $64294-100$.

643 Tobari, Y., Son, Y.L., Ubuka, T., Hasegawa, Y., Tsutsui, K., 2014. A new pathway mediating 644 social effects on the endocrine system: female presence acting via norepinephrine release 645 stimulates gonadotropin-inhibitory hormone in the paraventricular nucleus and 646 suppresses luteinizing hormone in quail. J. Neurosci. 34, 9803-9811.

647 Tsutsui, K., 2009. Review: A new key neurohormone controlling reproduction, gonadotropin648 inhibitory hormone $(\mathrm{GnIH})$ : Biosynthesis, mode of action and functional significance. 649 Prog. Neurobiol. 88, 76-88.

650 Tsutsui, K., Bentley, G.E., Bedecarrats, G.T., Osugi, T., Ubuka, T., Kriegsfeld, L.J., 2010a. 651 Review: Gonadotropin-inhibitory hormone $(\mathrm{GnIH})$ and its control of central and 652 peripheral reproductive function. Front. Neuroendocrinol. 31, 284-295.

653 Tsutsui, K., Bentley, G.E., Kriegsfeld, L.J., Osugi, T., Seong, J.Y.,Vaudry, H., 2010b. Review: 654 Discovery and evolutionary history of gonadotropin-inhibitory hormone and kisspeptin: 655 new key neuropeptides controlling reproduction. J. Neuroendocrinol. 22, 716-727. 
656 Tsutsui, K., Saigoh, E., Ukena, K., Teranshi, H., Fujisawa, Y.,Kikuchi, M., 2000. A novel avian

657

658

659

660

661

662

663

664

665

666

667

668

669

670

671

672

673

674

675

676

677

678 hypothalamic peptide inhibiting gonadotropin release. Biochem. Biophys. Res. Commun. 275, 661-667.

Tsutsui, K., Ubuka, T., Bentley, G.E., Kriegsfeld, L.J., 2012. Review: Gonadotropin-inhibitory hormone (GnIH): discovery, progress and prospect. Gen. Comp. Endocrinol. 177, 305314.

Tsutsui, K., Ubuka, T., Yin, H., Osugi, T., Ukena, K., Bentley, G.E., Ciccone, N., Inoue, K., Chowdhury, V.S., Sharp, P.J., Wingfield, J.C., 2006. Review: Mode of action and functional significance of avian gonadotropin-inhibitory hormone (GnIH). J. Exp. Zool. 305A, 801-806.

Tsutsui, K., Ubuka, T., Yin, H. Osugi, T., Ukena, K., Bentley, G.E., Sharp, P.J.,Wingfield, J.C., 2007. Discovery of gonadotropin-inhibitory hormone in a domesticated bird, its mode of action and functional significance. J. Ornithol. (Supplement 2), S515-S520.

Tsutsui, K., Ubuka, T., Bentley, G.E.,Kriegsfeld, L.J., 2013. Review: regulatory mechanisms of gonadotropin-inhibitory hormone $(\mathrm{GnIH})$ synthesis and release in photoperiodic animals. Frontiers Neurosci. 7, 1-11.

Ubuka, T., Haraguchi, S., Tobari, Y., Narihiro, M., Ishikawa, K., Hayashi, T., Harada, N.,Tsutsui, K., 2014. Hypothalamic inhibition of socio-sexual behavior by increasing neuroestrogen synthesis. Nature Commun. DOI: 10.1038/ncomms4061

Ubuka, T., Kim, S., Huang, Y.C., Reid, J., Jiang, J., Osugi, T., Chowdhury, V.S., Tsutsui, K., Bentley, G.E., 2008a. Gonadotropin-inhibitory hormone neurons interact directly with gonadotropin-releasing hormone-I and -II neurons in European starling brain. Endocrinology 149, 268-278. 
679 Ubuka, T., McGuire, N.L., Calisi, R.M., Perfito, N.,Bentley, G.E., 2008b. The control of 680 reproductive physiology and behavior by gonadotropin-inhibitory hormone. Integ. Comp. $681 \quad$ Biol. $48,560-569$.

682 Ubuka, T., Mizuno, T., Fukuda, Y., Bentley, G.E., Wingfield, J.C.,Tsutsui, K., 2013a. RNA 683 interference of gonadotropin-inhibitory hormone gene induces aggressive and sexual 684 behavior in birds. Gen. Comp. Endocrinol. 181, 179-186.

685 Ubuka, T., Mukai, M., Wolfe, J., Beverly, R., Clegg, S., Wang, A., Hsia, S., Li, M., Krause, J.S., 686 Mizuno, T., Fukuda, Y., Tsutsui, K., Bentley, G.E., Wingfield, J.C., 2012. RNA 687 interference of gonadotropin-inhibitory hormone gene induces arousal in songbirds, PLoS $688 \quad$ One 7, e30202.

689 Ubuka, T., Son, Y.L., Bentley, G.E., Millar, R.P.,Tsutsui, K., 2013b. Gonadotropin-inhibitory 690 hormone (GnIH), GnIH receptor and cell signaling. Gen. Comp. Endocrinol. 190, 10-17.

691 Visser, M.E., 2008. Keeping up with a warming world; assessing the rate of adaptation to climate 692 change. Proc. R. Soc. B 275, 649-659.

693 Visser, M.E., Caro, S.P., van Oers, K., Schaper, S.V., Helm, B., 2010. Phenology, seasonal 694 timing and circannual rhythms: toward a unified framework. Phil. Trans. R. Soc. B 365, $695 \quad 3113-3127$.

696 Visser, M.E., te Marvelde, L.,Lof, M.E., 2012. Adaptive phonological mismatches of birds and 697 their food in a warming world. J. Ornithol. 153 (Suppl), S-75-S84.

698 Wingfield, J.C., 2006. Communicative behaviors, hormone-behavior interactions, and 699 reproduction in vertebrates. In "Physiology of Reproduction" (J.D. Neill et al. ed.), 1995$700 \quad$ 2040, Academic Press, New York. 
701 Wingfield, J.C., 2008a. Organization of vertebrate annual cycles: implications for control 702 mechanisms. Phil. Trans. R. Soc. B 363, 425-441.

703 Wingfield, J.C., 2008b. Comparative endocrinology, environment and global change. Gen. Comp. $704 \quad$ Endocrinol. 157, 207-216.

705 Wingfield, J.C., 2012. The challenge hypothesis: behavioral ecology to neurogenomics. J.

706 Ornithol. DOI 10.1007/s10336-012-0857-8

707 Wingfield, J.C., 2015. Coping with change: a framework for environmental signals and how 708 neuroendocrine pathways might respond. Front. Neuroendocrinol. (in press).

709 Wingfield, J.C., Doak, D., Hahn, T.P., 1993. Integration of environmental cues regulating 710 transitions of physiological state, morphology and behavior. In "Avian Endocrinology"

711 (P.J. Sharp ed.), pp. 111-122, J. Endocrinol. Ltd., Bristol, U.K.

712 Wingfield, J.C. Farner, D.S., 1978. The endocrinology of a naturally breeding population of the 713 white-crowned sparrow (Zonotrichia leucophrys pugetensis). Physiol. Zool. 51, 188-205.

714 Wingfield, J.C., Farner, D.S., 1979. Some endocrine correlates of renesting after loss of clutch or 715 brood in the white-crowned sparrow, Zonotrichia leucophrys gambelii. Gen. Comp.

$716 \quad$ Endocrinol. 38, 322-331.

717 Wingfield, J.C., Farner, D.S., 1993. The endocrinology of wild species. In Avian Biology (D.S.

718 Farner, J.R. King, and K.C. Parkes, eds.), vol 9, pp. 163-327, Academic, New York.

719 Wingfield, J. C., Hahn, T. P., Levin, R., Honey, P., 1992. Environmental predictability and 720 control of gonadal cycles in birds. J. Exp. Zool. 261, 214-231.

721 Wingfield, J.C., Hegner, R.E., Dufty, A.M.Jr., Ball, G.F., 1990. The "challenge hypothesis":

722 theoretical implications for patterns of testosterone secretion, mating systems, and 723 breeding strategies. Am. Nat. 136, 829-846. 
724 Wingfield, J.C., Jacobs, J.D., Tramontin, A.D., Perfito, N., Meddle, S., Maney, D.L., Soma, K.,

725 1999. Toward and ecological basis of hormone-behavior interactions in reproduction of

726 birds. In " Reproduction in Context" (K. Wallen and J. Schneider eds.), pp. 85-128, M.I.T.

$727 \quad$ Press, Cambridge.

728 Wingfield, J.C., Mukai, M., 2009. Endocrine disruption in the context of life cycles:

729 environmental perturbations, global change and the adrenocortical response to stress. Gen.

$730 \quad$ Comp. Endocrinol. 163, 92-96.

731 Wingfield, J.C., Silverin, B., 2002. Ecophysiological studies of hormone-behavior relations in

732 birds. In: Hormones, Brain and Behavior, D.W. Pfaff, A.P. Arnold, A.M. Etgen, S.E.

733 Fahrbach, and R.T. Rubin Eds. Vol. 2, pp. 587-647, Elsevier Science, Amsterdam.

734 Wingfield, J.C., Silverin, B., 2009. Ecophysiological studies of hormone-behavior relations in

735 birds. In "Hormones, Brain and Behavior, $2^{\text {nd }}$. Edition" (D.W. Pfaff, A.P. Arnold, A.M.

736 Etgen, S.E. Fahrbach, and R.T. Rubin eds.), Vol. 2, pp. 587-647. Acad. Press. New York.

737 Wu, M., Dumalska, I., Morozova, E., van den Pol, A.N., Alreja, M. 2009. Gonadotropin

738 inhibitory hormone inhibits basal forebrain vGluT2-gonadotropin-releasing hormone

739 neurons via a direct postsynaptic mechanism, J Physiol. 587, 1401-1411.

740 Yin, H., Ukena, K., Ubuka, T., Tsutsui, K., 2005. A novel G protein-coupled receptor for

741 gonadotropin-inhibitory hormone in the Japanese quail (Coturnix japonica):

742 identification, expression and binding activity. J. Endocrinol. 184, 257-266.

743 Yokoyama, K., Farner, D.S., 1976. Photoperiodic responses in bilaterally enucleated female

744 white-crowned sparrows, Zonotrichia leucophrys gambelii. Gen. Comp. Endocrinol. 30,

$745 \quad 528-533$. 
746 Yoshimura, T., 2004. Molecular bases for seasonal reproduction in birds. J. Poultry Sci. 41, 251-

$747 \quad 258$.

748 
Figures.

750 Figure 1. The reproduction life history stage is made up of three distinct phases. First the

751 development phase in which the gonads reach maturity and the animal is capable of reproduction.

752 Second is the phase when actual onset of reproduction can take place. This may involve onset of

753 estrus in mammals or yolk deposition leading to ovulation in egg-laying vertebrates. Parental

754 care can be included in this phase. The third phase is termination of reproduction when cycling

755 in females ceases and in many seasonally breeding animals the gonads regress. From Wingfield

756 (2006), courtesy of Elsevier.

757

758

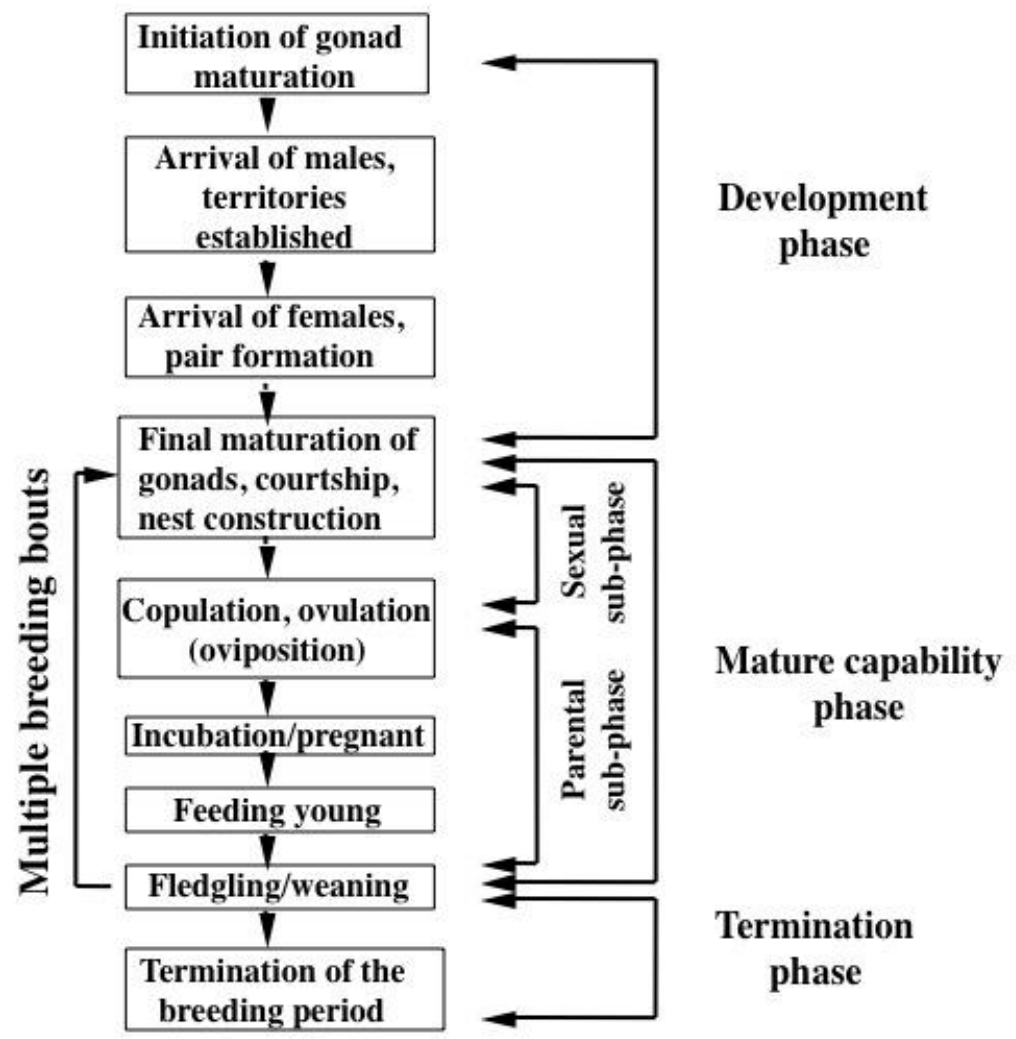


761 Figure 2. Different types of environmental signals from the physical environment and from 762 social interactions can influence all three phases of the reproduction life history stage. Initial

763 predictive information initiates gonadal development, maintains reproductive capacity and then

764 terminates the breeding season. Local predictive and synchronizing and integrating information can influence all three phases too. Thus knowing phase of the reproduction life history stage will be an important determinant of how, for example, a given behavioral interactions will affect neuroendocrine and endocrine mechanisms. From Wingfield (2006), courtesy of Elsevier.

\section{Life History Stage (LHSs) - Phases and Roles of Proximate Factors}
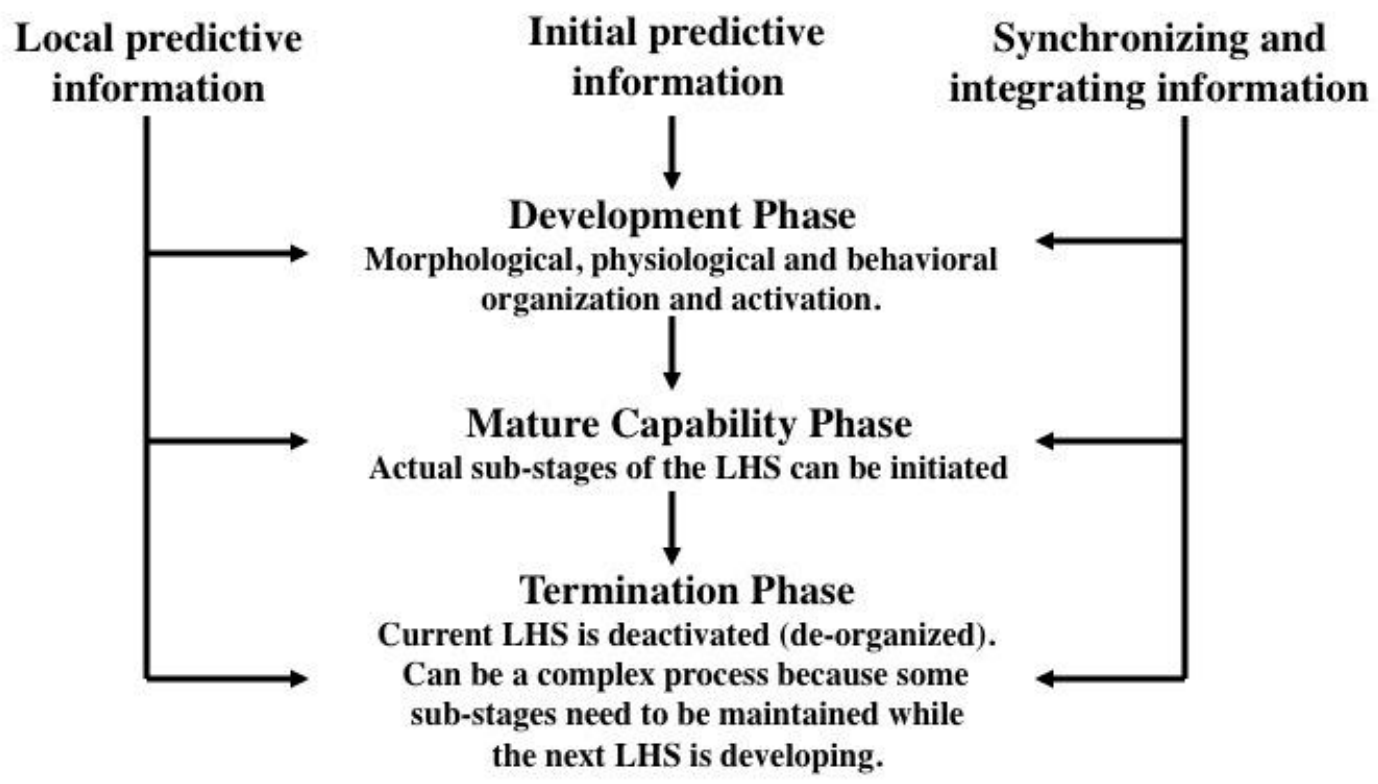
Figure 3. Ovarian and testicular development, and plasma levels of immunoreactive luteinizing hormone (irLH) and estradiol throughout the year in free-living white-crowned sparrows, Zonotrichia leucoprhys gambelii. The pale bars represent additional increases in ovarian follicle that occur during onset of nesting. These increases are primarily incorporation of yolk into follicle prior to ovulation. This is the "final oocyte maturation" sub-stage and is also accompanied by further increases in irLH and estradiol. Note that in males, testis size remains relatively stable after arrival and throughout the rest of the breeding season. Redrawn from

778 Wingfield and Farner (1978).

779
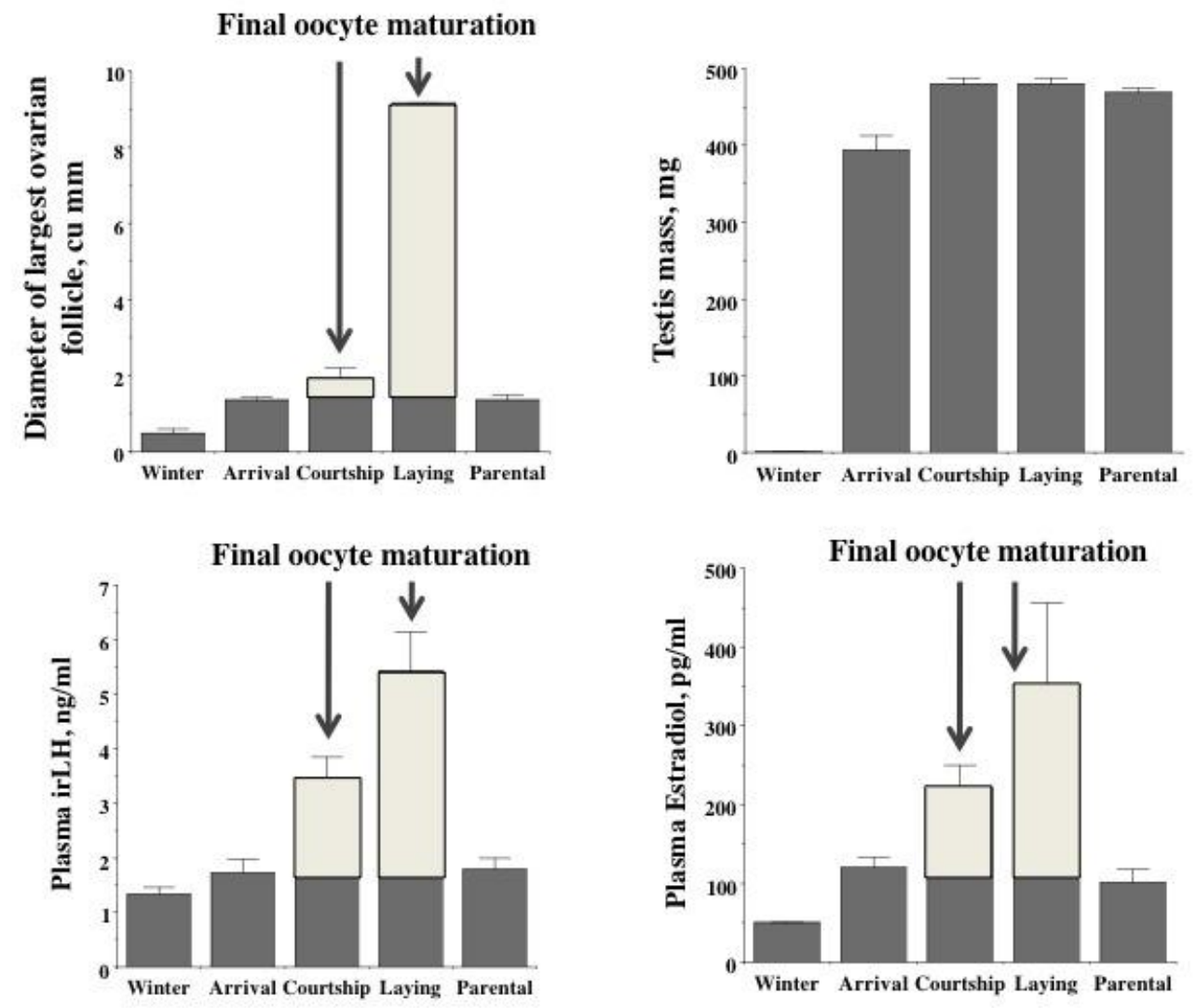
Figure 4. Schematic diagram showing how development of the ovarian follicles reaches mature capability and then holds for the entire breeding season until termination results in regression of the ovary to a non-breeding state (top panel). The dark triangle indicates when onset of nesting is triggered accompanied by a further increase in ovarian follicle development leading to ovulation (mid panel). Note that after the clutch of eggs is laid, ovarian development returns to that typical of mature capability. The bottom panel shows that this final maturation of ovarian follicles leading to ovulation can occur at any time appropriate during the mature capability phase. This might be production of a second or third clutch after successfully raising young in a previous brood, or could be a re-nesting attempt after an earlier nest was lost to a predator (from Wingfield and Farner, 1978, 1979, 1993).

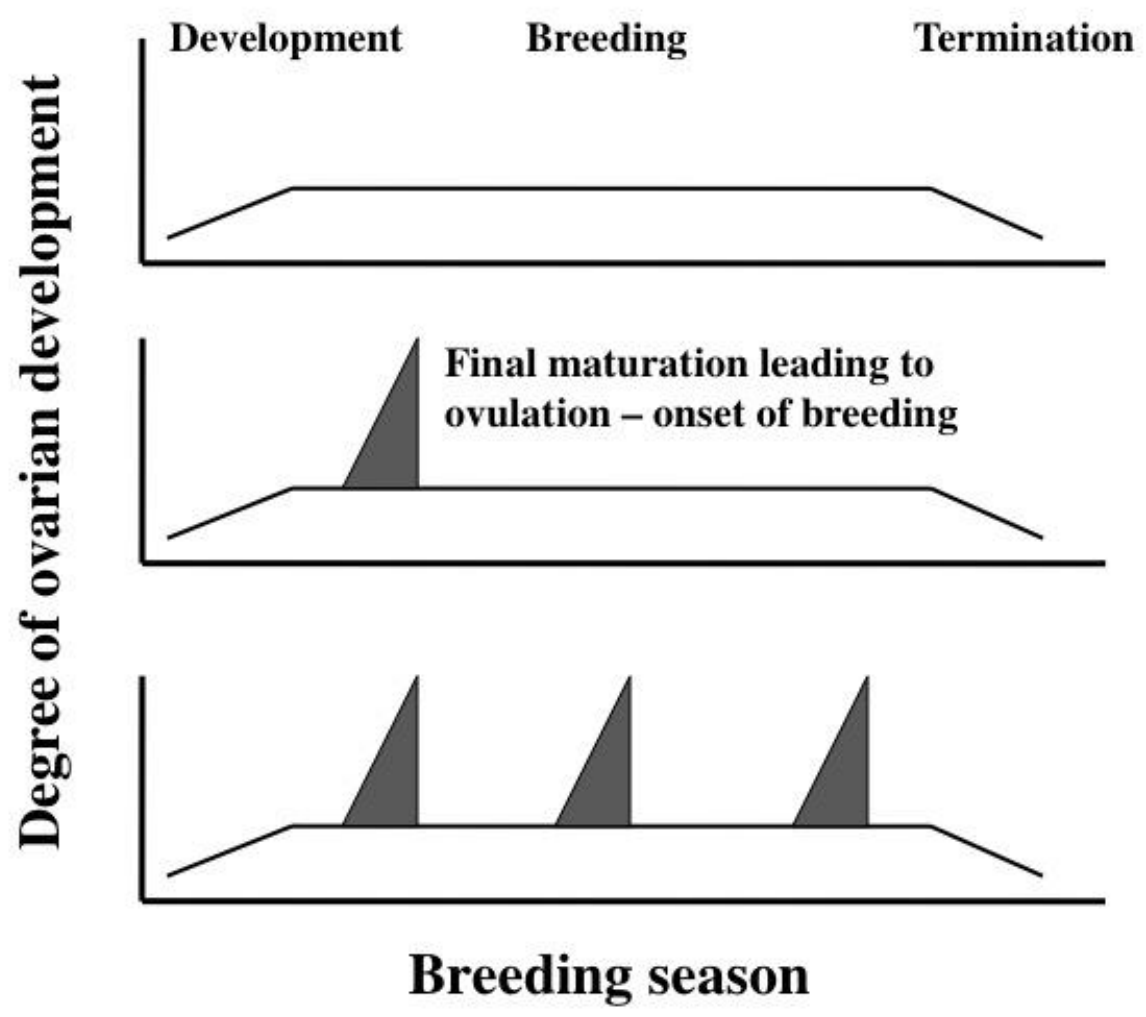

794

795

796 
797 Figure 5. Volume of the largest ovarian follicle in wild female song sparrows, Melospiza melodia, 798 photostimulated in captivity versus females that were hand-raised in captivity and kept over 799 winter in cages prior to photostimulation. Hand raised females showed much larger follicles with 800 yolk suggesting final maturation of follicles had begun. Wild caught females progressed only to 801 the pre-yolk deposition phase of follicular growth suggesting that there is a brake on final 802 maturation. Difference is significant, Mann-Whitney U test. J.C. Wingfield, unpublished.

803

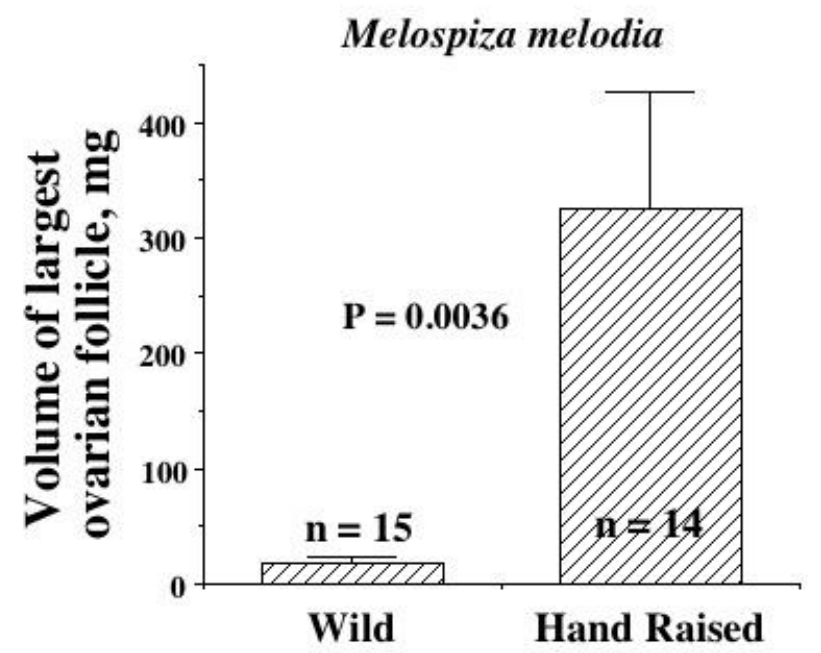

804 
805 Figure 6. Visual information may release an inhibition on gonadotropin release in female white806 crowned sparrows. Changes in plasma concentrations of LH of unilateral enucleates (red line, $\mathrm{N}$ $807=5$ ), bilateral enucleates (blue line, $\mathrm{N}=8$ ), and intact females (black line, $\mathrm{N}=8$ ). Redrawn from 808 Yokoyama and Farner (1976). Courtesy of Elsevier.

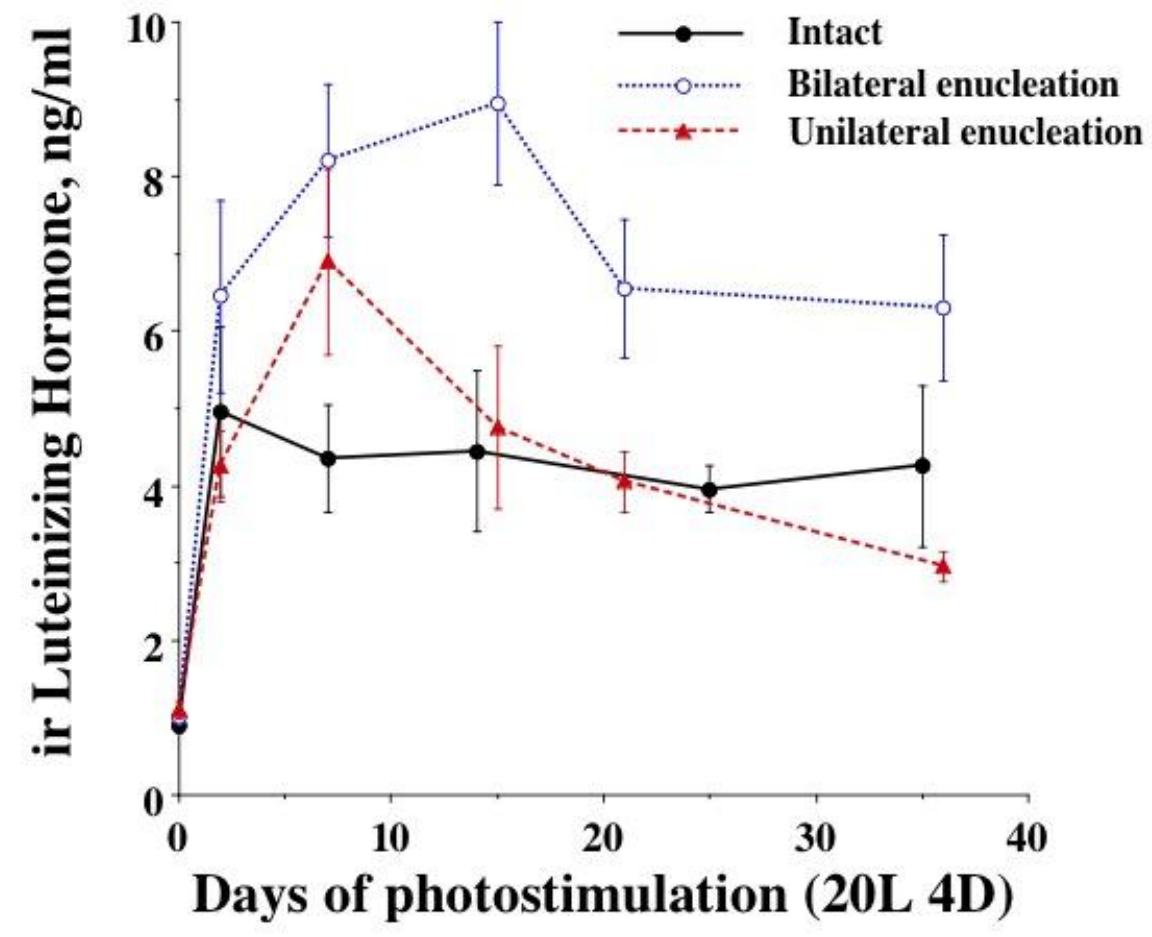

809

810 
811 Figure 7. We manipulated vision by gluing small plastic caps (kindly provided by Prof. Kenneth 812 Able, SUNY, Albany) over both eyes. The feathers were first removed around the eyes and then 813 caps were fitted and secured with Skinbond or Nexaband ( veterinary glue (Veterinary Products 814 Laboratories). Neoprene glue (McNett Corp.) applied to the circumference of the caps further 815 fixed the caps in place and prevented birds from loosening caps with their claws. Birds 816 acclimated first to one eye cap, followed the next day to both eyes capped. Caps were checked 817 regularly. The three treatment groups consisted of birds with: 1) black caps that blocked all 818 visual stimuli, 2) fogged caps that allowed light to penetrate, but prevented resolution of images, 819 and 3) clear caps that allowed normal vision (controls). Control caps worn by white-crowned

820 sparrows and western song sparrows were small plastic rings that were the same diameter and 821 glued in the same way as experimental caps, but did not cover the eyes. Eastern song sparrow 822 controls wore caps that were identical to experimental caps, but were clear. Un-manipulated 823 males were kept in individual cages in the same room with female white-crowned sparrows and 824 western song sparrows, but not with eastern song sparrows. N. Perfito and J.C. Wingfield, 825 unpublished.

826

UNCAPPED
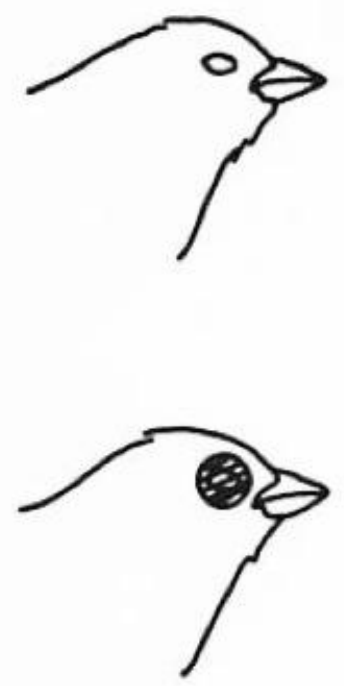

OPAQUE
CLEAR
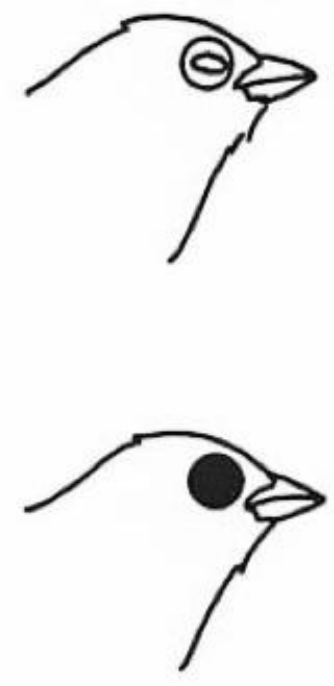

BLACK 
829 Figure 8. Differences among groups in the concentration of plasma LH were tested using one830 way ANOVA. Differences in follicle volume among treatment groups were tested using with a 831 nonparametric procedure (Kruskal-Wallis ANOVA with Dunn's Method for pairwise

832

833 comparisons) because variance was unequal among groups, and not normally distributed in some 834 cases. N. Perfito and J.C. Wingfield, unpublished.
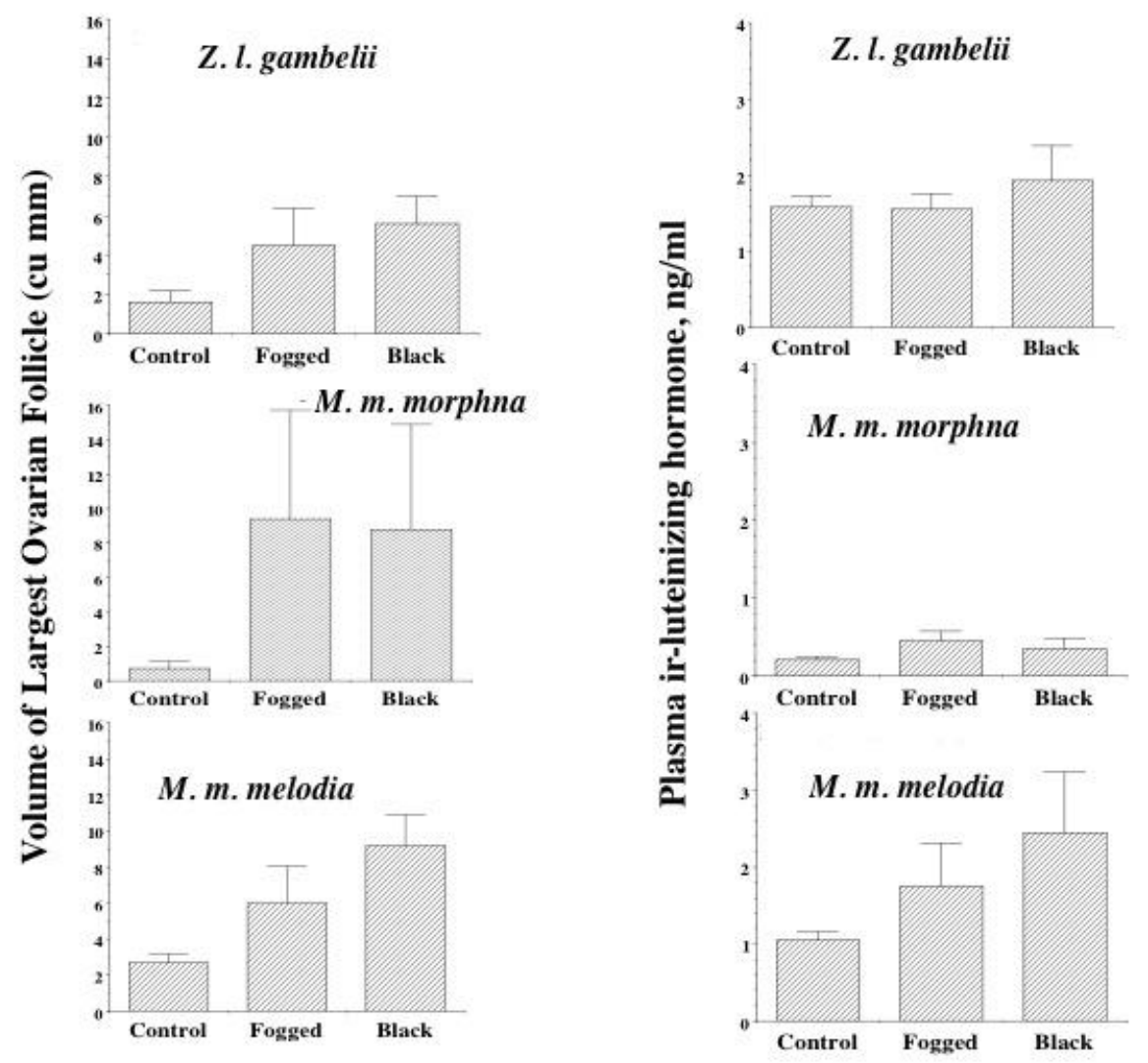
837 Figure 9. Effects of various GnIH treatments in plasma levels of immunoreactive luteinizing 838 hormone (irLH) in white-crowned sparrows, Zonotrichia leucophrys gambelii (Bentley et al., 839 2003; Osugi et al., 2004; O’Brien, 2009). Note that in the center top panel GnIH is most effective 840 in suppressing GnRH-induced surges of irLH. Central injection (top left) or peripheral infusion 841 via a min-osmotic pump (top right) are effective in decreasing breeding baseline plasma irLH. In 842 free-living males breeding in the North Slope of Alaska, highest irLH levels occur early in the 843 breeding season and can be decreased by GnIH injection (both left panel). Breeding baseline of

844 irLH later in the breeding season were not affected by GnIH consistent with GnIH having a 845 "brake" function to inhibit surges of LH associated with onset of nesting. From Bentley et al. 846 2003, O’Brien, 2009.

847
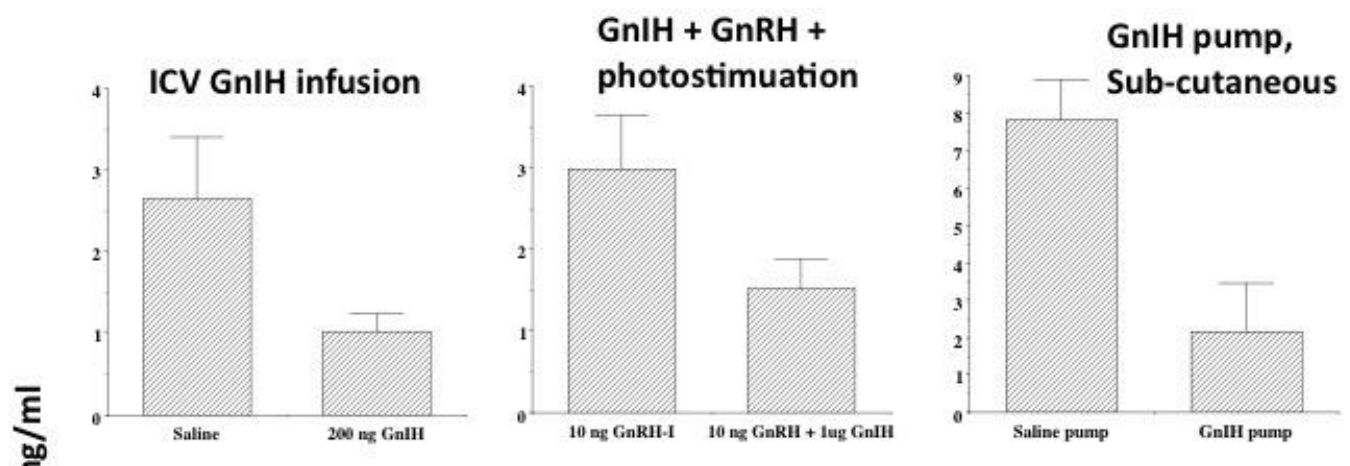

GnIH injection, male Z.I. gambelii, Toolik Lake, Alaska
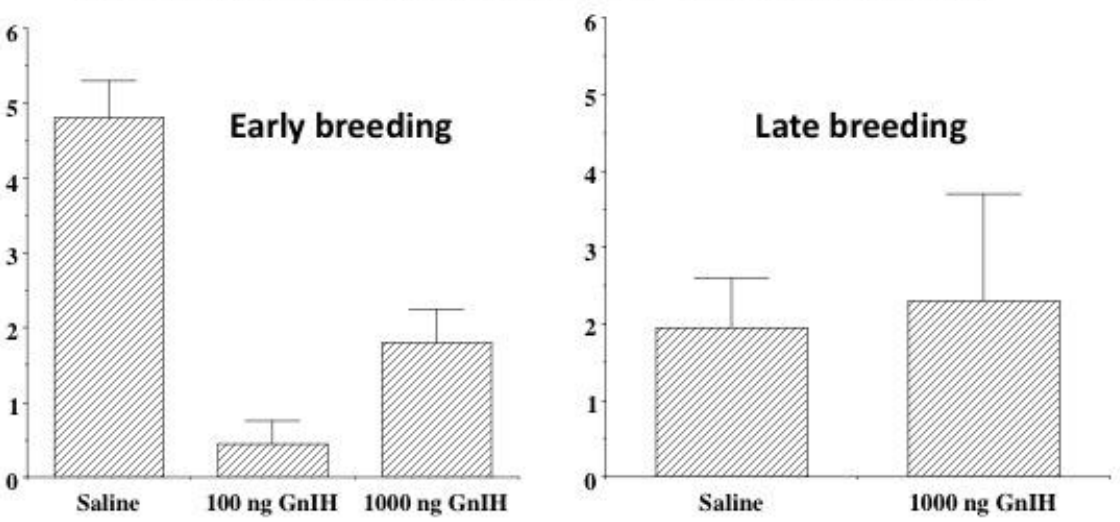

849

850 